\title{
The Impact of E-commerce on Travel Agencies Profitability in Respect of Size: Evidence from the U.S
}

\author{
Malik R. Elhaj ${ }^{1, *}$, Mohammed Z. Barakeh ${ }^{2}$ \\ ${ }^{1}$ Department of Accounting \& Finance, Prince Mohammad Bin Fahd University (PMU), Kingdom of Saudi Arabia \\ ${ }^{2}$ Barakeh Travel Inc., USA
}

Copyright $(\subset 2015$ by authors, all rights reserved. Authors agree that this article remains permanently open access under the terms of the Creative Commons Attribution License 4.0 International License

\begin{abstract}
The problem addressed in the proposed study was that the impact of E-commerce on traditional travel agencies has not been thoroughly examined, indicating that the disintermediation will continue to limit the success of these agencies. The current study consisted of an examination the impact of E-commerce in the profitability and the sustainability of travel agencies in respect of size, to determine if these perceptions vary as a function of the size of the travel agency. In addition, quantitative survey data was used to achieve the purposes of this study. The participants in this study were U.S. citizen's traditional travel agent who experiences the E-commerce impact. The results indicated that travel agents from larger agencies tended to believe that the effect of E-commerce on travel agencies was smaller than did travel agents from smaller agencies. The second conclusion from this study was that the participants felt confident that the need travel agents would remain in the coming years. In addition, we presented the current strategies used by the travel agencies and our suggestions to remain competitive.
\end{abstract}

Keywords E-commerce, Size, Travel Agent, Traditional, Brick-and-motor, Profitability

\section{Introduction}

Today's business environment is changing and technological environments challenge retail travel consultants on the functions they perform in distribution and sale of travel products. Traditional supplier, intermediaries and consumers seeking for information about booking, accommodation, transport, and destination is a process where they had their own role using their specific information system.

Information technology has a significant impact on businesses and consumers. Consumers have become possible through the Internet. E-commerce has affected the traditional brick-and-mortar travel agencies. The entire tourism industry structure is changing, the issue is how much of an effect that E-commerce have had on traditional agencies, and if it is to the point of making them obsolete. In previous studies regarding the impact of E-commerce mainly focused on disintermediation of brick-and-mortar travel agencies as threat, Marcussen [11]. The travel agent's perception's regarding the impact of E-commerce on the traditional travel agencies has not been studied adequately.

\section{Research Questions and Hypotheses}

Based on the purpose of this study, one research questions was developed with two hypotheses. The quantitative hypotheses were developed to address the relationships between travel agents' perceptions regarding the impact of E-commerce on brick-and-mortar travel agencies and travel agency size.

RQ. What are the factors that affect travel agent's perceptions regarding the impact of E-commerce on brick-and-mortar travel agencies in respect of travel agency size?

The following hypotheses were developed for the research question:

$\mathbf{H}_{\mathbf{0}}$. Travel agents' perceptions regarding the impact of E-commerce on brick-and-mortar travel agencies do not change with the respect to the agency size.

H1. Travel agents' perceptions regarding the impact of E-commerce on brick-and-mortar travel agencies change with the respect to the agency size.

\section{Definitions}

Traditional travel agent: A traditional travel agent is a travel agent who sells travel related products and services to customer, on behalf of suppliers, such as airlines, car rental companies, cruise lines, and so forth.

E-commerce: E-commerce is economic activities involving the sale and purchase of tangible goods or 
intangible services over the Internet, (Bontis \& Castro [4].

\section{Importance of the Study}

Researchers have not fully explored the effects of travel agency size of the E-commerce impact on brick-and-mortar travel agencies. One study, conducted in Taiwan, did explore this issue with 133 travel agents working at brick-and-mortar agencies, Bennett \& Lai [3]. The authors compared three groups of agencies: small agencies (with fewer than 20 employees), medium-sized agencies (with between 21 and 50 employees), and large agencies (with more than 50 employees). Travel agents from agencies defined by size were compared on a variety of measures in this survey study including perceived advantages of E-commerce for their work and the purposes for which they used the Internet. Bennett and Lai [3] found no significant differences between the three groups of agencies. However, this result has not been verified in travel agencies outside of Taiwan, and Bennett and Lai concluded that "a comparison of different countries would be valuable to assess how the impact of the Internet varies according to geography" (p. 21). The proposed study will fill this gap in the literature. From studying the perceptions of travel agent's regarding the impact of E-commerce on brick-and-mortar travel agencies will establish sufficient strategies to gain competitive advantages in the travel industry.

\section{Literature Review}

E-commerce has been introduced by information technology through the being development of the Internet and the World Wide Web. These technologies have impacted both consumer and industry behaviors in the areas of travel and tourism. Consumers have more options to search for vacations and budget planning. According to Xinran, Dae-Young, \& Morrison [16], over 95\% of web users have searched the Internet to gather travel related information, while $93 \%$ visited destination web sites and nearly one half used E-mails to gather travel-related information.

Information technology has an enormous role in the growth and improvement of the travel and tourism industry. The long-lasting effects of technology are improved information accessibility, higher level of competition, and a larger market of consumers and businesses around the world. According to Xinran et al. [16], the Internet reduced barriers to entry for E-commerce businesses. The great advantage of E-commerce is the cost saving and the profit increase to companies all around the world. According Drickhamern [6], $76 \%$ of most industries quoted that E-commerce is a major key of strength with information technology to drive growth and increase of profit.

Emarketer.com predicted the sales of online travel booking such as (air, car, and hotel) will increase $13.7 \%$ to 51.4 billion by 2010 . Hospitality Net (2011) predicted direct sales by supplier to customers will increase of $22 \%$ in 2010 to $30 \%$ in 2012 , which will reduce the commissions that is paid to travel agencies. Hotel-Online.com report increase $7 \%$ to $30 \%$ between 1998 and 2002 of online booking. Although there is a tremendous increase of the use of online booking, but there is many travelers prefer traditional travel agents. According to hotel- online.com $56 \%$ of business travelers use a traditional travel agent for air, and 35\% for hotel. The U.S. customer is primarily concerned with price and quickness when booking online.

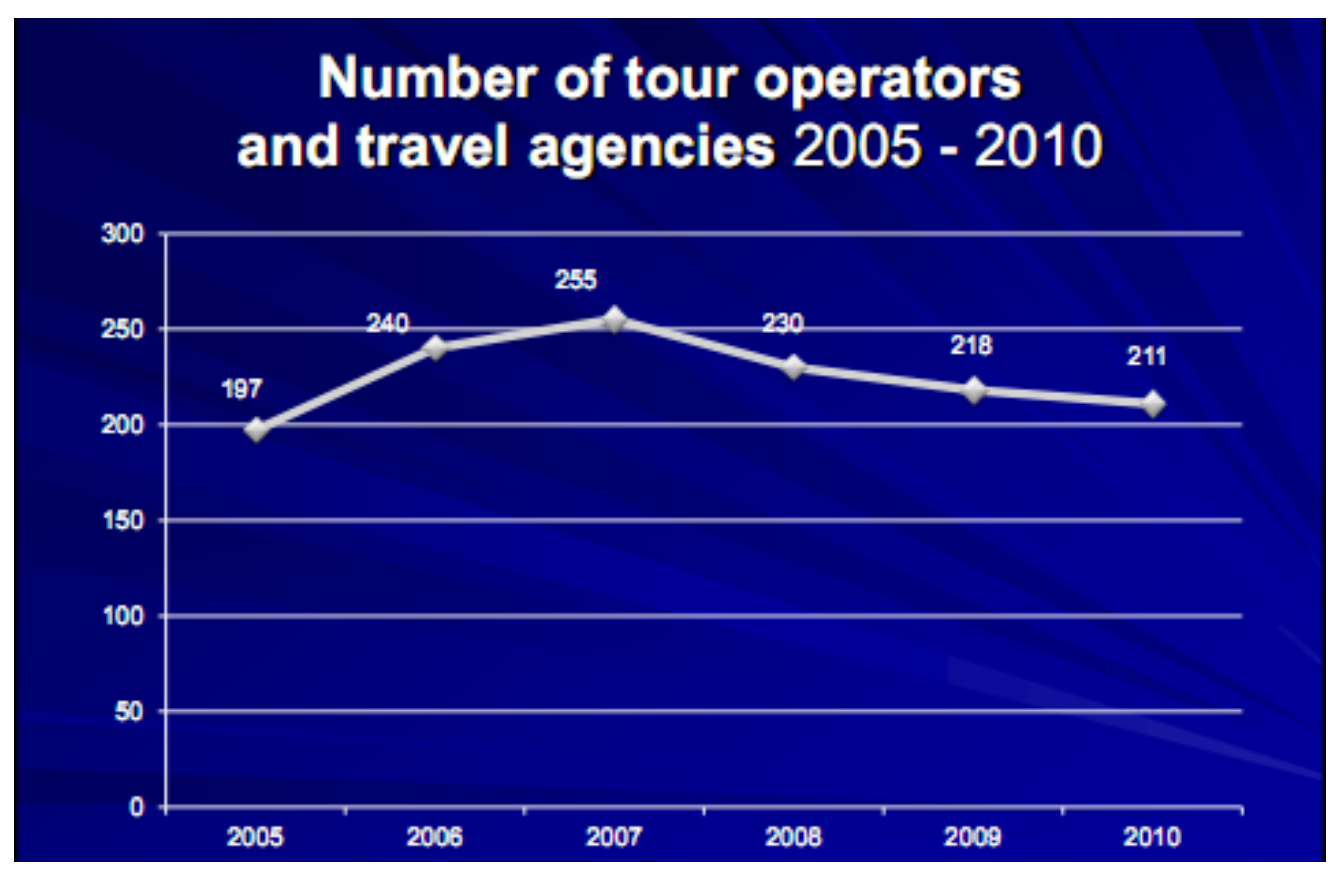

Figure 1. Number of Travel Agencies from 2005 to 2010 
The Airline Reporting Corporation (ARC) did report a decline in travel agencies locations due to commission reductions initiated in 1995. In March of 2010, U.S. Census Bureau reported 15,670 brick -and-mortar travel agencies and tour operators located in the U.S. In Figurel show the number of traditional travel agencies that directly sell tickets required to be an ARC accreditation to be able to issue tickets in their office. The decline of travel agent of having an ARC accreditation, because they stop issuing tickets in their office or are not selling airline tickets but instead are focusing on more profitable by selling tour packages and cruise.

According World Tourism Organization (2008), smalland medium-sized businesses are facing difficultly in adopting information technology, especially as it relates to E-commerce. The major problem relates to the affordability and the implementation of new information technology within a fast growing and changing organizations. Alexander, Pearson, \& Crosby [1] studied small and medium size traditional travel agencies that transferred their business to E-business. According to Alexander and Pearson, brick-and-mortar travel agencies must identify their market niche, and then invest in information technology, and also top management must provide training and support for themselves and their employees to able to adopt to new technology. The brick-and-mortar agencies must find a way to change business strategy to offer services not just locally but also globally for them to able to compete in the E-business market.

Chau [5] interviewed 34 small and medium size brick-and-mortar business owners in Australia in various E-commerce industries. The researcher compared four types of business such as education, travel agencies, manufacturing, and finance. As the results of the study, companies will benefit from E-commerce if they correspond to the changes in the process of the organizational structure. According to APE more than $80 \%$ of E-commerce sales are done by small and medium business. Small and medium business plays an important role in E-business major players in E-business. E-commerce will give small and medium business a great competitive advantage, market niche, and will expand in E-business market.

\subsection{The Role of Traditional Travel Agencies}

The role of traditional travel agents was wholesales, tour organizer, middleman, and adviser between the suppliers and customers, Vasudavan \& Standing [15]. Recently, all the information that was provided by the traditional travel agents has been given directly to customers via online booking (online travel agencies). Customers are becoming more educated of the use of online booking. As a result customers could book their own air, hotel, car, or do a bundle all three as one package and get a lower rate with no need of a traditional travel agent.

Travel agencies exist primarily as intermediaries between suppliers of travel services, Dolnicar \& Laesser [7] such as airlines and hotels, and customers. Travel agent is defined as a person who undertakes a job for another person, who is the principal. The principal in such a relationship not only sets the goals of the job, such as selling tickets, but may also control the means and manner in which the job is done, Tsaur, Liang, \& Hsiao, [14]. The fundamental role of a travel agency can be broadly summarized as: information, distribution, reservation and services.

\begin{tabular}{|c|c|}
\hline $\begin{array}{c}\text { "Arguments for the disintermediation } \\
\text { of travel agencies" }\end{array}$ & $\begin{array}{l}\text { Arguments against the disintermediation } \\
\text { of travel agencies }\end{array}$ \\
\hline $\begin{array}{l}\text { Travel agencies merely manage information } \\
\text { and undertake reservations } \\
\text { Travel agencies are biased, in favor of } \\
\text { principals who offer override commissions } \\
\text { and in-house partners } \\
\text { Experienced travelers are much more } \\
\text { knowledgeable than travel agencies } \\
\text { Personnel in travel agencies are often } \\
\text { inadequately trained and inexperienced } \\
\text { There is a gradual increase of independent } \\
\text { holidays and a decrease of package holidays } \\
\text { Technology enables consumers to undertake } \\
\text { most functions from the convenience of their } \\
\text { armchairs } \\
\text { Electronic travel intermediaries offer a greater } \\
\text { flexibility and more choice } \\
\text { A number of themed/specialized web portals } \\
\text { emerge to serve niche markets }\end{array}$ & $\begin{array}{l}\text { - Travel agencies are professional travel advisers and offer } \\
\text { valuable services and advice } \\
\text { Travel agencies use expertise to save time for consumers } \\
\text { - Technology is difficult to use and expensive to acquire for } \\
\text { individuals } \\
\text { A large part of the market is computer illiterate and unwilling to } \\
\text { improve its skills } \\
\text { Travel agencies offer free counseling services and add value by } \\
\text { giving advice } \\
\text { - } \\
\text { Electronic intermediaries primarily serve the business market } \\
\text { and are more expensive } \\
\text { There is currently limited provision online for the organized } \\
\text { inclusive tourist } \\
\text { Travel agencies can achieve better prices through the right } \\
\text { channels and deals and by buying in bulk or through } \\
\text { consolidators }\end{array}$ \\
\hline
\end{tabular}




\section{Methodology}

\subsection{Research Design}

A mixed-method research design was used in this study. Mixed-method studies consist of both a quantitative component and a qualitative component. The quantitative portion of this study employed an ex-post facto research design. Ex-post facto research designs are used to examine relationships and group differences based on preexisting characteristics of a group, Creswell [6]. In the proposed study, the preexisting characteristics were size of firm, the independent variable in this study. The dependent variable was the travel agents' perception regarding the impact of E-commerce on the traditional travel agencies. Given that the independent variables in an ex post facto study such as the proposed study were preexisting conditions and not experimentally manipulated, causal inference cannot be drawn regarding the effects of the independent variables on the dependent variable.

The qualitative portion of this study employed a phenomenological research design. In a phenomenological study, "Researchers search for essentials, invariant structure (or essence) or the central underlying meaning of the experience" (Creswell, 1998, p. 52). The participants in this study, traditional travel agents, have experiences relevant to the proposed topic and therefore were able to provide valid opinions regarding the effects of E-commerce on traditional travel agencies. The qualitative portion of this study was relatively minor and consisted of an examination of responses to two open-ended questions at the end of the survey.

\subsection{Selection of Participants}

The population of interest in this study consisted of travel agents employed at brick-and-mortar travel agencies in the United States. The sample consisted of travel agents at brick-and-mortar travel agencies in the United States who consented to participate in this study. A marketing research firm was used to assemble a sample of participants who meet these criteria.

A statistical power analysis was performed to determine the sample size required for the proposed study. For the power analysis, two-tailed tests, and alpha level of .05, desired power of .80 , and medium effect sizes were specified. The G*Power computer program, Version 3.0, Faul, Erdfelder, Lang, \& Buchner [10] was used to perform the power analysis. As discussed in the Data Analysis section of this chapter, the primary inferential technique to be employed in this study consists of a set of Pearson correlation coefficients. For the Pearson correlation coefficients, a medium effect size of $\rho=.30$ was specified, and $G^{*}$ Power indicated that 84 participants would be required to achieve power of 80 . Based on the results from the power analysis, the minimum required sample size for this study was set at 84 .

\subsection{Instrumentation}

A survey was developed for this research study based on the research question presented above to explore the participants' opinions regarding the impact of E-commerce travel agencies size. Eight items were contained in this section, and the participants were asked to respond using a 5-point Likert scale ranging from strongly disagree (which will be coded as 0 ) to strongly agree (which will be coded as 4). Each of the eight items related to the effect of E-commerce travel agencies on traditional travel agencies. Agreement with Items 1, 3, 4, and 5 indicated that the participant believes that E-commerce travel agencies have a negative impact on traditional travel agencies. Agreement with Items 2, 6, 7, and 8 indicated that the participant believes that E-commerce travel agencies do not have a negative impact on traditional travel agencies. Items $2,6,7$, and 8 were reverse scored, and a total impact score was computed by summing the responses to the eight items. This served as the primary dependent variable in this study.

In addition, the survey consisted of two open-ended questions that were used for the qualitative portion of this study. The two open-ended questions were: "What is the impact of E-commerce travel agencies on traditional travel agencies?" and "As a traditional travel agent, what strategies do you use to remain competitive with E-commerce travel agencies?" The verbatim responses of the participants to these two questions were recorded and used for the content analysis discussed in the Data Analysis section.

\subsection{Data Analysis}

A Cronbach's alpha internal consistency reliability coefficient was computed for this score to ensure that it meets the minimum reliability criterion of .70 . If the reliability of the Total Impact score did not reach this level, revisions to the survey would have been made including the revision of items that did not contribute to the reliability of the score and replacing them with additional items.

For the main study data, both descriptive and inferential statistical analyses were performed. Initially, descriptive statistics were computed for all study variables. This consisted of means and standard deviations for all continuous variables and frequencies and percentages for all categorical variables. Inferential analyses were then performed to test the null hypotheses of this study. Inferential analyses were performed using two-tailed tests and an alpha level of .05. The research question of this study was: What are the factors that affect travel agent's opinions regarding the impact of E-commerce on brick-and-mortar travel agencies in respect of size? The null hypothesis for this research question was:

H1 $1_{0}$. Travel agents' perceptions regarding the impact of E-commerce on brick-and-mortar travel agencies do not change with the respect to the agency size.

The dependent variable for this hypothesis was the Total Impact score discussed above. This is an interval-level 
composite variable, and therefore the Pearson correlation between the travel agency size (assessed as the number of employees) and the Total Impact score was used to test this hypothesis.

A content analysis of the participants' responses to the two open-ended survey questions was then performed. According to Elo and Kyngas, [9] content analysis is an analysis method "for making replicable and valid inferences from data to their context, with the purpose of providing knowledge, new insights, a representation of facts and a practical guide to action" (p. 108). The primary goal of the content analysis performed in the proposed study was to identify the major themes related to the impact of E-commerce travel agencies on traditional travel agencies and the strategies used by traditional travel agents to remain competitive with E-commerce travel agencies. Initially, the responses to the two open-ended questions were read. Then, preliminary coding categories were developed and the responses were coded as to the presence or absence of each coding category. Based on the preliminary coding and the review of the responses, the final set of codes was developed and the responses were coded according to the presence or absence of each code. The dominant codes (i.e., those that occur most frequently) were then developed as the major themes and representative quotations were used to demonstrate the participants' perspectives related to each theme.

\section{Results}

\subsection{Sample Demographic and Background Characteristics}

The demographic and background characteristics of the sample are summarized in Table 1 . The sample was approximately evenly split between male $(49.0 \%)$ and female (51.0\%) respondents. Most of the participants (55.9\%) were married. In terms of ethnicity, nearly half of the sample was Caucasian/White (48.0\%), with 21.6\% Middle Eastern, $17.6 \%$ Hispanic, $7.8 \%$ African-American, and $4.9 \%$ Asian-American. The most common educational degree was a bachelor's degree $(45.1 \%)$ followed by an associate's degree $(32.4 \%)$, a master's degree $(11.8 \%)$, a doctorate (6.9\%), and a high school diploma (3.9\%).

\subsection{Travel Agency and Job-related Characteristics}

Table 2 shows descriptive statistics for the survey questions about the travel agency and job-related characteristics of the participants. The most common approximate annual sales volume for the travel agencies was between $\$ 5$ million and \$10 million (30.4\%). Relatively few agencies had very low annual sales volumes of less than $\$ 250,000(16.7 \%)$ or very large annual sales volumes of $\$ 10$ million or more $(10.8 \%)$. The location of most of the primary businesses was a travel agency $(66.7 \%)$. The participants indicated that their agency provided a variety of services including airline tickets (84.3\%), tours and packages $(83.3 \%)$, cruises $(67.6 \%)$, business travel $(52.0 \%)$, and luxury travel $(51.0 \%)$. Lower-end services such as bus and railroad tickets $(31.4 \%)$ and rental cars $(37.3 \%)$ were less common. All participants indicated that they used telephones to interact with clients, while $94.1 \%$ used face-to-face communication, $92.2 \%$ used email, and $45.1 \%$ used online booking engines.

Table 1. Descriptive Statistics for the Demographic and Background Characteristics of the Sample $(\mathrm{N}=102)$

\begin{tabular}{ccc}
\hline Variables & Frequency & Percentag \\
Gender & & \\
& & \\
Male & 50 & 49.0 \\
Female & 52 & 51.0
\end{tabular}

Marital Status

$\begin{array}{lcc}\text { Single } & 22 & 21.6 \\ \text { Married } & 57 & 55.9 \\ \text { Separated } & 8 & 7.8 \\ \text { Widowed } & 3 & 2.9 \\ \text { Divorced } & 7 & 6.9 \\ \text { ng with partner } & 5 & 4.9\end{array}$

Ethnicity

$\begin{array}{ccc}\text { African-American } & 8 & 7.8 \\ \text { Caucasian/White } & 49 & 48.0 \\ \text { Middle Eastern } & 22 & 21.6 \\ \text { Asian-American } & 5 & 4.9 \\ \text { Hispanic } & 18 & 17.6\end{array}$

Educational attainment

$\begin{array}{ccc}\text { High school } & 4 & 3.9 \\ \text { Associate's degree } & 33 & 32.4 \\ \text { Bachelor's degree } & 46 & 45.1 \\ \text { Master's degree } & 12 & 11.8 \\ \text { Doctorate } & 7 & 6.9\end{array}$


Table 2. Descriptive Statistics for the Travel Agency Characteristics of the Sample $(\mathrm{N}=102)$

\begin{tabular}{|c|c|c|}
\hline Characteristic & Frequency & Percentage \\
\hline \multicolumn{3}{|l|}{ Approximate annual sales volume } \\
\hline Less than $\$ 250,000$ & 17 & 16.7 \\
\hline$\$ 250,000$ to $\$ 499,999$ & 10 & 9.8 \\
\hline$\$ 500,000$ to $\$ 999,999$ & 0 & 0.0 \\
\hline$\$ 1,000,000$ to $\$ 2.9$ million & 14 & 13.7 \\
\hline$\$ 3.0$ million to $\$ 4.9$ million & 19 & 18.6 \\
\hline$\$ 5.0$ million to $\$ 9.9$ million & 31 & 30.4 \\
\hline$\$ 10.0$ million or more & 11 & 10.8 \\
\hline \multicolumn{3}{|l|}{ Location of the primary business } \\
\hline $\begin{array}{c}\text { Travel agency (physically located on the } \\
\text { premises) }\end{array}$ & 68 & 66.7 \\
\hline Home-based travel agent & 28 & 27.5 \\
\hline Travel industry supplier & 6 & 5.9 \\
\hline Tour operator & 10 & 9.8 \\
\hline \multicolumn{3}{|l|}{ Services provided } \\
\hline Airline tickets & 86 & 84.3 \\
\hline Luxury travel & 52 & 51.0 \\
\hline Business travel & 53 & 52.0 \\
\hline Tours and packages & 85 & 83.3 \\
\hline Cruises & 69 & 67.6 \\
\hline Travel insurance & 49 & 48.0 \\
\hline Rental cars & 38 & 37.3 \\
\hline Bus and railroad tickets & 32 & 31.4 \\
\hline Group travel & 43 & 42.2 \\
\hline \multicolumn{3}{|l|}{ Methods used to interact with customers } \\
\hline Face-to-face & 96 & 94.1 \\
\hline Telephone & 102 & 100.0 \\
\hline Online booking engine & 46 & 45.1 \\
\hline E-mail & 94 & 92.2 \\
\hline \multicolumn{3}{|l|}{$\begin{array}{l}\text { Has the growth of Internet sales in your } \\
\text { company over the last 2-3 years been } \\
\text { higher or lower than you expected? }\end{array}$} \\
\hline Higher & 19 & 18.6 \\
\hline Lower & 8 & 7.8 \\
\hline Same & 40 & 39.2 \\
\hline Don’t know & 35 & 34.3 \\
\hline \multicolumn{3}{|l|}{$\begin{array}{l}\text { What, if anything, has been the impact of } \\
\text { your online presence upon your offline } \\
\text { sales? }\end{array}$} \\
\hline Offline sales have increased & 2 & 2.0 \\
\hline It has made no difference to offline sales & 14 & 13.7 \\
\hline Offline sales have decreased & 10 & 9.8 \\
\hline $\begin{array}{l}\text { There is no relationship between our } \\
\text { online presence and offline sales }\end{array}$ & 13 & 12.7 \\
\hline Do not have an online presence & 42 & 41.2 \\
\hline Do not have an offline presence & 0 & 0.0 \\
\hline Don’t know & 21 & 20.6 \\
\hline Characteristic & $M$ & $S D$ \\
\hline $\begin{array}{c}\text { Number of branch office of your current } \\
\text { employer }\end{array}$ & 2.44 & 4.55 \\
\hline $\begin{array}{c}\text { Number of employees at your current } \\
\text { employer }\end{array}$ & 5.93 & 5.34 \\
\hline $\begin{array}{c}\text { Percentage of sales volume made via the } \\
\text { Internet }\end{array}$ & 15.32 & 21.82 \\
\hline $\begin{array}{l}\text { Percentage of sales volume to be made } \\
\text { via the Internet over the next } 3 \text { years }\end{array}$ & 21.69 & 25.95 \\
\hline
\end{tabular}

Growth in Internet sales in the past 2 to 3 years tended to be as expected $(39.2 \%)$ as or higher than expected $(34.3 \%)$. In regard to how an online presence has affected offline scales, $41.2 \%$ of the participants indicated that they do not have an online presence and another $20.3 \%$ indicated that they did not know how their online presence has affected their offline sales. Of the remainder, most participants felt that their online presence made no difference in their offline sales $(13.7 \%)$ or, similarly, that there was no relationship between the online presence and offline sales.

The average number of years as a traditional travel agent was 13.12 years $(S D=11.64$ years $)$. The number of branch offices averaged $2.44(S D=4.55)$ while the number of employees averaged $5.93(S D=5.34)$. The participants reported that an average of $15.32 \%$ of their sales volume was made via the Internet $(S D=21.82)$, and that they expected that an average of $21.69 \%$ of their sales volume would be made via the Internet in the next 3 years $(S D=25.95)$.

\subsection{Impact of E-Commerce Travel Agencies}

Table 3 contains descriptive statistics (i.e., levels of agreement) for the perceptions of the impact of E-commerce travel agency items. The items to which the largest percentage of participants agreed were Item 7, "Traditional travel agencies will continue to remain competitive because some corporate customers prefer the personal service they offer" (with 37.6\% strongly agreeing and 39.6\% agreeing), Item 6, "Traditional travel agencies will continue to remain competitive because some customers prefer face-to-face transactions" (with $37.6 \%$ strongly agreeing and $34.7 \%$ agreeing), and Item 8, "Traditional travel agencies will continue to remain competitive because some customers do not use the Internet" (with 35.6\% strongly agreeing and $37.6 \%$ agreeing).

It was clear from these responses that many the participants tended to feel that traditional travel agencies would continue to remain competitive in the future. The item with the highest level of disagreement was Item 1, "E-commerce travel agencies have devastated traditional travel agencies" (with $21.6 \%$ strongly disagreeing and $31.4 \%$ disagreeing), again indicating that the participants did not feel that traditional travel agencies had been rendered obsolete by E-commerce travel agencies.

Null Hypothesis . The null hypothesis of this study was:

$\mathbf{H}_{0}$. Travel agents' perceptions regarding the impact of E-commerce on brick-and-mortar travel agencies do not change with the respect to the agency size. 
Table 3. Descriptive Statistics for the Perceptions of the Impact of E-Commerce Travel Agency Items $(\mathrm{N}=102)$

\begin{tabular}{|c|c|c|c|c|c|}
\hline Item & $\begin{array}{l}\text { Strongly } \\
\text { disagree }\end{array}$ & Disagree & Neutral & Agree & $\begin{array}{c}\text { Strongly } \\
\text { agree }\end{array}$ \\
\hline $\begin{array}{l}\text { 1. E-commerce travel agencies have devastated } \\
\text { traditional travel agencies. }\end{array}$ & $21.6 \%$ & $31.4 \%$ & $9.8 \%$ & $20.6 \%$ & $16.7 \%$ \\
\hline $\begin{array}{l}\text { 2. Traditional travel agencies have been positively } \\
\text { affected by E-commerce travel agencies. }\end{array}$ & $16.7 \%$ & $24.5 \%$ & $13.7 \%$ & $27.5 \%$ & $17.6 \%$ \\
\hline $\begin{array}{l}\text { 3. The low prices offered by E-commerce travel } \\
\text { agencies make it difficult for traditional travel } \\
\text { agencies to remain competitive. }\end{array}$ & $11.0 \%$ & $19.0 \%$ & $28.0 \%$ & $26.0 \%$ & $16.0 \%$ \\
\hline $\begin{array}{l}\text { 4. The variety of services offered by E-commerce } \\
\text { travel agencies makes it difficult for traditional } \\
\text { travel agencies to remain competitive. }\end{array}$ & $9.8 \%$ & $15.7 \%$ & $31.4 \%$ & $32.4 \%$ & $10.8 \%$ \\
\hline $\begin{array}{l}\text { 5. Traditional travel agencies will cease to exist in } \\
\text { the future because of E-commerce travel agencies. }\end{array}$ & $19.6 \%$ & $40.2 \%$ & $8.8 \%$ & $20.6 \%$ & $10.8 \%$ \\
\hline $\begin{array}{l}\text { 6. Traditional travel agencies will continue to } \\
\text { remain competitive because some customers } \\
\text { prefer face-to-face transactions. }\end{array}$ & $2.0 \%$ & $2.0 \%$ & $23.8 \%$ & $34.7 \%$ & $37.6 \%$ \\
\hline $\begin{array}{l}\text { 7. Traditional travel agencies will continue to } \\
\text { remain competitive because some corporate } \\
\text { customers prefer the personal service they offer. }\end{array}$ & $1.0 \%$ & $3.0 \%$ & $18.8 \%$ & $39.6 \%$ & $37.6 \%$ \\
\hline $\begin{array}{l}\text { 8. Traditional travel agencies will continue to } \\
\text { remain competitive because some customers do } \\
\text { not use the Internet. }\end{array}$ & $2.0 \%$ & $3.0 \%$ & $21.8 \%$ & $37.6 \%$ & $35.6 \%$ \\
\hline
\end{tabular}

Table 4 contains the correlations among Total Impact scores and years of experience. The correlation between Total Impact scores and agency size was $r=-.30(p=.002)$. This correlation was statistically significant and the null hypothesis was rejected. The negative correlation indicated that participants from smaller agencies perceived a greater impact of E-commerce on the traditional travel agencies than was the case for participants from larger agencies.

Table 4. Correlations Among Total Impact Scores and Agency Size $(\mathrm{N}=$ 102)

Variable Total Impact $\quad$ Agency Size

Total Impact

Agency Size $-.30 *$

$* p<.01$

\subsection{Qualitative Results}

The responses to two open-ended questions were also examined. The first open-ended question was: What is the impact of E-commerce travel agencies on traditional travel agencies? Table 5 shows the categorized responses to this question. An equal number of participants indicated that the impact was positive and negative (22.5\% each). Among those who stated that there was a positive impact, increased efficiency $(18.6 \%)$ and increases in the customer base (3.9\%) were the cited positive effects. Among those who felt that the impact was negative, decreases in sales, profits, or commissions $(11.8 \%)$ and increases in competition $(9.8 \%)$ were the common negative impacts. Some participants (3.9\%) felt that there was a neutral effect because traditional and online agencies attracted different audiences.

More participants felt that there was a positive effect of E-commerce travel agents on consumers (33.3\%) than felt that there was a negative impact (5.9\%). Among those who felt that there was a positive impact, increased transparency and choice $(22.5 \%)$ and impacts on pricing (17.6\%) were cited commonly. Those who felt that the impact was negative tended to see a decrease in customer service as the primary negative impact on consumers. Overall, $37.3 \%$ of the participants did not provide a response to this open-ended question. 
Table 5. Categorized Responses to the Question "What is the impact of E-commerce travel agencies on traditional travel agencies?" $(\mathrm{N}=102)$

\begin{tabular}{|c|c|c|}
\hline Perceived Impact Category & Frequency & Percentage \\
\hline $\begin{array}{c}\text { Positive Impacts on Traditional } \\
\text { Agencies }\end{array}$ & 23 & 22.5 \\
\hline Increases customer base & 4 & 3.9 \\
\hline Increases efficiency & 19 & 18.6 \\
\hline $\begin{array}{c}\text { Negative Impacts on Traditional } \\
\text { Agencies }\end{array}$ & 23 & 22.5 \\
\hline $\begin{array}{l}\text { Decreases sales, profit, or } \\
\text { commission }\end{array}$ & 12 & 11.8 \\
\hline $\begin{array}{l}\text { Overhead costs and local agency } \\
\text { presence }\end{array}$ & 2 & 2.0 \\
\hline Increased competition in general & 10 & 9.8 \\
\hline $\begin{array}{c}\text { Neutral Impacts on Traditional } \\
\text { Agencies }\end{array}$ & 4 & 3.9 \\
\hline $\begin{array}{l}\text { Different audiences relative to } \\
\text { traditional agencies }\end{array}$ & 2 & 2.0 \\
\hline $\begin{array}{l}\text { Minimal or no impact on } \\
\text { traditional agencies }\end{array}$ & 2 & 2.0 \\
\hline Positive Impacts on Consumers & 34 & 33.3 \\
\hline $\begin{array}{l}\text { Increases in consumer } \\
\text { transparency and choice }\end{array}$ & 23 & 22.5 \\
\hline Impacts on pricing & 18 & 17.6 \\
\hline Negative Impacts on Consumers & 6 & 5.9 \\
\hline $\begin{array}{l}\text { Decrease in customer service } \\
\text { relative to traditional agencies }\end{array}$ & 6 & 5.9 \\
\hline No response & 38 & 37.3 \\
\hline
\end{tabular}

Notes. Indented items represent the major themes contained in each category. Counts for each perceived impact category and associated themes are based on content analysis of open-ended responses across 102 participants.

The second open-ended question was: As a traditional travel agent, what strategies do you use to remain competitive with E-commerce travel agencies? Table 6 shows the categorized responses to this question. The most common strategies related to maintaining a customer service orientation $(29.3 \%)$ through providing high quality customer service through access to agents, face-to-face contact, and a human touch. Second, $18.6 \%$ of the participants took a value-added perspective, using strategies related to their knowledge, experience, and training.
Table 6. Categorized Responses to the Question "As a traditional travel agent, what strategies do you use to remain competitive with E-commerce travel agencies?" $(\mathrm{N}=102)$

\begin{tabular}{|c|c|c|}
\hline Perceived Impact Category & Frequency & Percentage \\
\hline $\begin{array}{l}\text { Customer service orientation (high } \\
\text { quality customer service, including } \\
\text { access to agents, face to face contact, the } \\
\text { human touch) }\end{array}$ & 30 & 29.4 \\
\hline $\begin{array}{l}\text { Value-added orientation (including } \\
\text { detailed knowledge, experiences, and } \\
\text { training possessed by traditional agents) }\end{array}$ & 19 & 18.6 \\
\hline Adopt E-commerce strategies and tools & 19 & 18.6 \\
\hline $\begin{array}{l}\text { Diversify across markets or populations } \\
\text { (target sectors or populations where } \\
\text { traditional agents have an advantage, like } \\
\text { group sales, groups who distrust online } \\
\text { booking, etc.) }\end{array}$ & 15 & 14.7 \\
\hline $\begin{array}{c}\text { Networking among customers and } \\
\text { suppliers (targeting loyal customers, } \\
\text { word of mouth, relationships with } \\
\text { suppliers) }\end{array}$ & 10 & 9.8 \\
\hline $\begin{array}{l}\text { Financial incentives for customers } \\
\text { (including price match, discounts, gifts) }\end{array}$ & 6 & 5.9 \\
\hline $\begin{array}{l}\text { Financial measures for traditional agents } \\
\text { (home office, annual fee instead of } \\
\text { commission) }\end{array}$ & 2 & 2.0 \\
\hline No response or won't share strategies & 37 & 36.3 \\
\hline
\end{tabular}

Notes. Counts for each perceived strategy category are based on content analysis of open-ended responses across 102 participants.

An additional $18.6 \%$ of the participants had used a strategy of adopting E-commerce strategies and tools. Other participants reported diversifying across markets (14.7\%), networking among customers and suppliers (14.7\%), offering financial incentives to customers (5.9\%), and other financial measures $(2.0 \%)$. A total of $36.3 \%$ of the participants did not provide a response to this open-ended question.

\subsection{Summary}

Psychometric results from the pilot study (based on 30 participants) and the main study (based on 102 participants) indicated that the Total Impact score was reliable. Descriptive statistics for the main study sample showed that:

1. The most common approximate annual sales volume for the travel agencies was between $\$ 5$ million and $\$ 10$ million (30.4\%).

2. The most common services provided were airline tickets $(84.3 \%)$, tours and packages $(83.3 \%)$, and 
cruises $(67.6 \%)$

3. Telephones $(100.0 \%)$, face-to-face contact $(94.1 \%)$, and E-mail (92.2\%) were the most common methods of communication with customers.

4. An average of $15.32 \%$ of annual sales volume was made via the Internet, and this was expected to increase to $21.69 \%$ in the next 3 years.

5. The participants tended to feel that traditional travel agencies would remain viable in the future because corporate customers prefer personal service and face-to-face transactions, and because some customers do not use the Internet.

Inferential analyses were then performed to test the two null hypotheses of this study. Results from the correlational analyses indicated that participants from smaller agencies perceived a greater impact of E-commerce on the traditional travel agencies than was the case for participants from larger agencies.

Finally, qualitative results showed that:

1. The participants were split between a belief that the impact of E-commerce on traditional travel agencies was negative or positive.

2. The participants were five times more likely to think that E-commerce travel agents had positive effects for consumers than to think that they had negative effects.

3. The most common strategies used to address the challenge brought about by E-commerce travel agencies included maintaining a customer service orientation (29.3\%), taking a value-added perspective, and adopting E-commerce strategies and tools.

In the next chapter these results are discussed in the context of past research in this area. In addition, recommendations are offered for travel agency practice and for future research in this area.

\section{Discussion}

This section contains a summary of the first four chapters of this study. The problem addressed in this study was that the effects of E-commerce on the retail travel agent business are unknown. Although some studies had been conducted into the disintermediation of brick-and-mortar travel agencies, Marcussen [11], no studies had been performed to examine the perceptions of travel agents regarding the impact of E-commerce on traditional travel agencies. Therefore, the purposes of this quantitative study were to explore brick-and-mortar travel agents' perceptions regarding the impact of E-commerce on the traditional travel agencies, to determine if these opinions vary as a function of years of travel agent experience in the travel industry.

The results indicated that there was a statistically significant and negative correlation between Total Impact scores and agency size $(r=-.30, p=.002)$. The first null hypothesis was rejected and it was concluded that travel agents from larger agencies perceived a smaller impact of E-commerce on the traditional travel agencies than was the case for participants from smaller agencies who perceived a larger impact of E-commerce.

The qualitative analysis of the responses to the open-ended questions indicated that:

1. An equal number of participants indicated that the impact of E-commerce on brick-and-mortar travel agencies was positive and negative.

2. Increased efficiency and increases in the customer base were the cited positive effects, while decreases in sales, profits, or commissions, and increases in competition were the common negative impacts.

3. In terms of the effects of E-commerce on consumers, the participants were more than five times more likely to see the effect as positive than negative.

4. Increased transparency and choice and lower prices were seen as the positive effects for consumers while a decrease in customer service was seen as the negative effect for consumers.

5. The most common strategies used by brick-and-mortar travel agents to respond to E-commerce challenges related to maintaining a customer service orientation through access to agents, face-to-face contact, and a human touch.

6. Other strategies including taking a value-added perspective using strategies related to their knowledge, experience, and training, adopting some E-commerce strategies and tools, diversifying across markets, and networking among customers and suppliers.

In the next sections, the primary conclusions from this study based on these results are provided and discussed in the context of past research in this area.

\section{Conclusions}

Based on the results from this study, three primary conclusions were drawn. First, in relation to the null hypothesis tests related to travel agency size it was concluded that travel agents from larger agencies ended to believe that the effect of E-commerce on brick-and-mortar travel agencies was smaller than did travel agents from smaller agencies. Although some past studies have indicated that E-commerce would be devastating for traditional travel agents, Ancker; Licate et al. [2]; McCubbrey [12], other studies have indicated that travel agents could prosper if they focused on providing good customer service (Naisbitt, 2001). Based on the results from the current study, it appears that more experienced agents from larger agencies have been more successful in making the transition to E-commerce in the travel industry.

The second conclusion from this study was that the participants felt confident that the need for brick-and-mortar 
travel agents would remain in the coming years. This conclusion is based on the descriptive statistical analyses in which it was determined that the majority of participants felt that traditional travel agencies would continue to remain competitive because some corporate customers prefer the personal service they offer, because some customers prefer face-to-face transactions, and because some customers do not use the Internet. However, other past studies have indicated that the Internet would pose a serious threat to brick-and-mortar travel agencies, Ancker; Licate et al. [2]. It appears that brick-and-mortar travel agents have been successful in adapting to E-commerce.

\section{Recommendations}

Based on the conclusions from this study, recommendations are offered in this section. Initially, recommendations for professional practice are provided. Then, recommendations for future research in this area are presented including those based on the limitations and delimitations of this study.

\subsection{Recommendations for Professional Practice}

It is recommended that travel agents with less experience and those from smaller travel agencies should adopt the recommended strategies in order to remain competitive in the changing travel industry. They may also benefit from taking a value-added perspective, adopting some E-commerce strategies and tools, diversifying across markets, and networking among customers and suppliers. If these steps are taken the negative effects of E-commerce on brick-and-mortar travel agents may be mitigated.

\subsection{Recommendations for Future Research}

There are four recommendations for future research based on the results, limitations, and delimitations of this study. One limitation of this study was a reliance on self-reports of perceptions, opinions, and attitudes. Although travel agent perceptions are important to consider, objective data could also be used to examine the effects of E-commerce on brick-and-mortar travel agents. Therefore, the first recommendation for future research is that future researchers in this area should combine objective data and self-report data. Objective data analyses could consist of reviews of accounting statements such as profit and loss statements segmented as a function of online revenues and traditional revenues, and so forth.

The primary delimitation of this study was that the participants were recruited through a marketing research firm database. That is, individuals in the marketing research firm's databases who met the conditions for participation in this study were the only individuals with a chance to participate. Many other travel agents were not members of this database and therefore did not have a chance to participate. To the extent to which the individuals within this database differed from those not in the database, the results from this study will have lessened generalizability. In addition, all of the participants in this study were currently working in the United States. Based on these limits to the generalizability of the findings from this study, the second recommendation for future research is that this study be replicated in other geographic locations with travel agents from different sampling pools so that the extent to which the current findings apply to other groups can be determined.

\section{REFERENCES}

[1] Alexander, C., J.M. Pearson, L. Crosby. (2003). "The transition to E-commerce: A study case study of a rural-based travel agency". Journal of Internet Commerce 2(1): 49-63.

[2] Anckar, B. (2003). Consumers' intentions in terms of electronic travel distribution. E-Service Journal, 2(2), 68-86. doi:10.1353/esj.2003.0009

[3] Bennett, M. M., \& Lai, C. K. (2005). The impact of the Internet on travel agencies in Taiwan. Tourism and Hospitality Research, 6(1), 8-23. Retrieved from http://thr.sagepub.com/

[4] Bontis, N. \& Castro, A. D. (2000), "The First World Congress on the Management of Electronic Commerce: Review and Commentary", Internet Research, Vol. 10, No. 5, pp. 365-374.

[5] Chau, S. (2003). "The use of E-commerce amongst thirty-four Australian SMEs: an experiment or a strategic business tool". Journal of Systems and Information Technology 7(1): 49-66.

[6] Creswell, J. W. (2009). Research design, qualitative, quantitative, and mixed methods approaches. Thousand Oaks, CA: Sage.

[7] Dolnicar, S., and Laesser, C. "ravel Agency Marketing Strategy: Insights from Switzerland". Journal of Travel Research (46:2), 2007, pp.133-146.

[8] Drickhamer, D. (2000, January 24). Section 4: Operations. Industry Week. Retrieved from http://www.industryweek.com/

[9] Elo, S., \& Kyngas, H. (2008). The qualitative content analysis process. Journal of Advanced Nursing, 62(1), 107-115. doi: 10.1111/j.1365-2648.2007.04569.x

[10] Faul, F., Erdfelder, .E, Lang, A. G., \& Buchner, A. (2007). G*Power 3: A flexible statistical power analysis program for the social, behavioral, and biomedical sciences. Research Methods, 39(2), 175-191. doi:10.3758/BF03193146

[11] Marcussen, C. H. (2008). Trends in European Internet distribution of travel and tourism services. Copenhagen, Denmark: Centre for Regional and Tourism Research,.

[12] McCubbrey, D. (1999). Disintermediation and reintermediation in the U.S air travel distribution industry: A Delphi study. Communications of the Association of Information Systems, 1(18), 1-16. Retrieved from http://aisel.aisnet.org/cais/ 
[13] Tsai, M. (2004, August 11). Web-travel sites are growing, but pace eases. Wall Street Journal, 4B.

[14] Tsaur, S. H., Yung, C. Y., \& Lin, J. H. (2010). The relational behavior between wholesaler and retailer travel agencies: Evidence from Taiwan. Journal of Hospitality \& Tourism Research, 30(3), 333-353. doi:10.1177/1096348006286796

[15] Vasudavan, T., \& Standing, C. (1999). The impact of the
Internet on the role of travel consultants. Participation \& Empowerment, 7(8), 213-226.

doi:10.1108/14634449910303595

[16] Xinran Y. Lehto, Dae-Young Kim, \& Alastainr M. (2006). The effect of prior destination experience on online information search behaivoir. Toursism and Hospital Research Vol. 6, no. 2, pp. 160-178. 